\section{Sponge Mortality at British Honduras}

A IIEAVY mortality among commercial sponges, similar to the Bahamas mortality reported by Galtsoff, Brown, Smith and Smith', has appeared among sponges off the coast of British Honduras. The disease appeared first in the Bahamas in December 1938, on the north coast of Cuba in February 1939, and at Key West, Florida, in March. Losses rere first reported from British Honduras in June and continued to appear during July and August.

Investigations were carried out in British Honduras by mo during August and have yielded the following results.

The sponges, for the most part under cultivation, grow upon grounds within Turneffo lagoon, which is enclosed by islands and communicates with the sea by small creeks and larger channels. The sequence of infection, as recorded by Government and privato sponge planters, has followred the general trend of water movements within the lagoon. Originating near a large opening from tho sea, the mortality spread first to the more open waters to leeward and only later appeared in more deeply embayed areas, and in areas broken up by small cays.

During the months of April, May and June rainfall was less than 25 per cent of the amount recorded in previous years and water temperatures wore generally higher. There is evidence that the salinity during Juno reached very high values, but unfortunately accurate figures are not available. In July and August the conditions of drought, high temperature and salinity were roplaced by normal conditions, and in August accurato determinations placed temperaturo and salinity within the range of observation for previous years, although the mortality remained unehecked.

Examination of plankton collected with 120 mesh per inch silk townet during August showed no unusual constituents or abnormal quantities of tho species normally present. In accordance with previous examinations, a general paucity of lifo was disclosed.

Tho microplankton was also poor, except for tho presence of bacteria, considered to bo the food of the sponges. Bacterial examination showed $2,000-30,000$ organisms per e.c. in various parts of the lagoon during August. This compared with 2,000-25,000 observed during May.

No unusual mortality was observed among other forms of life in the lagoon. Non-commercial sponges remained unaffected by the disaster.

Microscopic investigation disclosed the presence of fungus-like filaments in the great majority of dying sponges examined. In appearance, spread of infection through the individual sponge, and greater abundance in the transition zone between dead and living tissues, the organism was indistinguishable from that held probably responsible for tho Balamas diseaso. Apart from the fungal filaments no organisms have been observed other than those characteristically appearing after the onset of decay.

The successive appearance of the mortality at Koy West and at Turneffe and the local progress of the mortality along the path of water currents renders it probable that the disease organism was transmitted from Key West to Turneffe by an ocean current. The strong current running counter to the Gulf Stream along the shores of the Gulf of Mexico and the Gulf of Campeche has a velocity varying from 0.5 to 2 knots. The time elapsed between the appearanco of sponge damage at Key West and at Turnefe is ample for trunsmission of the organism by this current.

At the time of writing no further damage has been reported from Turneffo since the middle of August. F. G. Walton Simth.

Spongo Fishery Investigations,

Nassau, N.P., Bahamas.

Sept. 11.

'NATURe, 143, 807 (1939).

\section{Transplants of Sea-Island Cotton}

Witr regard to the statement made by Prof. Nacbrido in NaTURE of February 4, p. 205, that "the effort to transplant sea-island cotton from islets off the coast of Carolina to other parts of the world has resulted in failure. In a fow years tho transplanted cotton reverts to the native stock", the following facts, which do not quite support this viow, may be of interest.

Sea-island cotton has been grown at the Government Agricultural Farm, Sakrand, Sind, for at least ten years, and the samples raised at this Farm have been regularly tested at this Laboratory sinco 192030. It has been found that in the second year of tests (1930-31) the mean fibre-length dropped from $\mathbf{1 . 4 4}$ in. to 1.25 in., but sinco then it has remained more or less the same with the exception of 1936-37 when it declined temporarily to $1 \cdot 18$ in. The mean fibre-weight per inch has remained remarkably steady at about $0 \cdot 117 \times 10^{-8} \mathrm{oz}$. From the Farm the cotton spread to the cultivators' field, and in 1935-36 the area under its cultivation stood at 1,400 acres, giving a crop of about sovon hundred bales. Since then tho area has decreased sharply, not because of any deterioration in its fibre-properties, but because of its poor yield, which prevented the cultivators from getting adequate monetary return for their labour.

It will thus be seen that at least during the last ten years it has not roverted, when grown in Sind, to the native stock, which is a neglectum typo having a mean fibre-length of about $0 \cdot 70$ in. and a fibreweight per inch of about $0.300 \times 10^{-6} \mathrm{oz}$, that is, nearly half as long and three times as coarse in staple as tho Sind sea-island cotton. Its yield, however, has not been satisfactory, and it may be said to have failed on that account.

$$
\begin{gathered}
\text { Cotton Technological Laboratory, } \\
\text { Natunga, Bombay. } \\
\text { Sept. 1. }
\end{gathered}
$$

\section{Myzus ornatus a Vector of Potato Viruses}

Towarns the end of 1932, aphids later identified as Myzus ornatus ${ }^{1}$ were found feeding on clover plants in a glasshouse at the Agricultural College, Glasnevin. The species has since been recorded on a wide host range which includes potatoes, a fact which prompted the carrying out of tests to ascertain the efficiency of this species as a vector of potato viruses.

It was used in three separate trials as a vector of leaf roll, ind tho results showed that out of sixteen healthy potato plants colonized with MIyzus ornatus from a leaf roll source, ten developed leaf roll. In two trials as a vector of virus $Y$, five out of sixteen healthy potato plants became infected with this virus. Negative results have so far been obtained in trials with viruses $\mathrm{X}$ and $\mathrm{A}$. 